\title{
Ichthyotoxicity of gymnodinioid dinoflagellates: PUFA and superoxide effects in sheepshead minnow larvae and rainbow trout gill cells
}

\author{
Ben D. Mooney ${ }^{1, *}$, Juan José Dorantes-Aranda ${ }^{1}$, Allen R. Place ${ }^{2}$, \\ Gustaaf M. Hallegraeff ${ }^{1}$

\footnotetext{
${ }^{1}$ University of Tasmania, Institute for Marine and Antarctic Studies, Private Bag 55, Hobart, Tasmania 7001, Australia
} \\ ${ }^{2}$ Institute of Marine and Environmental Technology, University of Maryland Center for Environmental Sciences, Baltimore, \\ Maryland 21202, USA
}

\begin{abstract}
While $24 \mathrm{~h}$ exposure of sheepshead minnow fish larvae to purified monogalactosyl diglyceride (MGDG) lipids, containing octadecapentaenoic acid (OPA) exclusively or as a mixture of octadecatetraenoic acid, eicosapentaenoic acid, and OPA (OTA-EPA-OPA), caused sluggish swimming and gulping, it produced no mortalities even at concentrations up to $120 \mathrm{mg} \mathrm{l}^{-1}$. In contrast, comparable concentrations and exposure times caused significant reductions in viability of rainbow trout gill cells. Pure EPA was the most harmful to gill cells (up to $98.5 \%$ viability loss in $60 \mathrm{~h}$ ) followed by OPA-rich MGDG ( $45 \%$ loss), with OTA-rich MGDG (37\% loss) the least toxic. OPA-pure MGDG was non-toxic to rainbow trout gill cells; however, surprisingly, pure palmitic acid was harmful $(40 \%$ viability loss), and we conclude that gill cell line toxicity of the OPA-rich MGDG fraction was caused by admixture with palmitic acid. Screening of 15 Kareniaceae dinoflagellate species demonstrated that these species are low (on average 10 times less) producers of superoxide compared to the ichthyotoxic raphidophyte Chattonella marina. No mortality of sheepshead minnow fish larvae occurred when exposed to superoxide alone or superoxide combined with either OPA-rich MGDG or OTA-rich MGDG. Superoxide showed a slight impact on viability of rainbow trout gill cells. In conclusion, synergistic interactions between free fatty acids and reactive oxygen species as previously claimed for raphidophytes could not be confirmed. Gill damaging effects from EPA were conclusively demonstrated, however; when these co-occurred with OTA, a higher loss of viability was observed (up to $37 \%$ ), suggesting a magnified toxic effect. Contradictory literature claims as to the ichthyotoxicity of OPA (nontoxic in our work) may relate to the presence of chemical impurities.
\end{abstract}

KEY WORDS: Kareniaceae · Ichthyotoxicity · Octadecapentaenoic acid · OPA · Polyunsaturated fatty acid $\cdot$ PUFA $\cdot$ Superoxide

\section{INTRODUCTION}

Fragile, athecate, Kareniaceae species have been associated with mortalities of finfish worldwide, with the principal site of impact consistently observed to be the sensitive gills, thus causing hypoxia and impacts on blood osmolality. A full understanding of the fishkilling mechanism has been elusive however. In the ab- sence of a specific toxin, such as brevetoxin in Karenia brevis and karlotoxin in Karlodinium veneficum (Mooney et al. 2009), research to find a toxic mechanism in other dinoflagellates such as Karenia mikimotoi has focused on lipids such as polyunsaturated fatty acids (PUFAs) (Arzul et al. 1998, Fossat et al. 1999, Sola et al. 1999, Gentien et al. 2007). Cold-adapted algae often have elevated levels of PUFAs to maintain cellular 
function, as these molecules remain fluid at lower temperatures (Valentine \& Valentine 2004). Using bioassay-guided fractionation, the most common PUFAs investigated for toxic activity are octadecatetraenoic acid (OTA), octadecapentaenoic acid (OPA), eicosapentaenoic acid (EPA), and docosahexaenoic acid (DHA). These molecules are highly reactive, contain 4 to 6 double bonds, and are short-lived in the water column (Jüttner 2001). PUFAs are synthesized almost entirely in the plastid, with the majority of OPA and OTA present in plastid-related glycolipids, as mono- or digalactosyl diglycerides (MGDG and DGDG) (Bell et al. 1997, Leblond \& Lasiter 2009), and with EPA and DHA dominant in the cell-membrane phospholipid fraction (Leblond \& Chapman 2000, Adolf et al. 2007). Upon lysis of senescent cells and/or dinoflagellate cell implosion upon contact with fish gills, the algal cells may rupture and release a cocktail of reactive and potentially toxic lipids. Many Kareniaceae species contain appreciable relative levels of the PUFAs OPA, EPA, and DHA (Mooney et al. 2007). However, with the ichthyotoxic haptophyte Chrysochromulina polylepis, differences between toxic and non-toxic strains could not be simply attributed to OPA lipids (John et al. 2002).

In addition to PUFAs, reactive oxygen species (ROS), measured as superoxide, have been implicated as contributing to mass mortalities of fish (Kim et al. 1999, Yamasaki et al. 2004). ROS are produced by both animal and plant cells in biochemical processes. Living cells have protective systems designed to prevent oxidative damage. ROS are short-lived oxygen free radicals that include superoxide $\left(\mathrm{O}_{2}{ }^{-}\right)$, the hydroxyl radical $\left(\mathrm{OH}^{-}\right)$and hydrogen peroxide $\left(\mathrm{H}_{2} \mathrm{O}_{2}\right)$. ROS are toxic in their own right, causing cellular damage by degrading organic molecules such as lipids, proteins, and nucleic acids, and consequently have been implicated in fish kills via damage to gills through lifting of the epithelial layer and affecting gas exchange (Shimada et al. 1991). Production of ROS is closely linked to photosynthesis, with higher levels produced during exponential growth and during the day (Marshall et al. 2002). Algal species producing significant levels of ROS investigated in conjunction with ichthyotoxic blooms include the dinoflagellates Cochlodinium polykrikoides (Kim et al. 1999, 2002) and Karenia mikimotoi (Yamasaki et al. 2004), and raphidophytes such as Chattonella marina (Oda et al. 1992a,b, Marshall et al. $2005 a, b)$. Ichthyotoxicity to damselfish by EPA, as the free acid, increased 3 -fold in the presence of superoxide and was claimed as the toxic principle in Chattonella marina (Marshall et al. 2003).

Here, we investigate superoxide production by Kareniaceae and explore synergistic ichthyotoxicity of purified MGDG, with OPA or OTA, using both whole fish bioassays as well as a novel gill cell line assay.

\section{MATERIALS AND METHODS}

Algal strains and growth conditions. For ROS experiments, non-axenic cultures of 23 species of toxic and non-toxic marine algae (Table 1) were maintained in ESAW (enrichment solution artificial seawater) (Berges et al. 2001), f/2 (f medium of Guillard and Ryther at half strength) (Andersen et al. 1997), or GSe (medium $\mathrm{G}$ with selenium added) (Blackburn et al. 1989) at 15 to 32 salinity and at 14,17 , or $20^{\circ} \mathrm{C}$. A $12 \mathrm{~h}$ light:12 h dark cycle of $80 \mu \mathrm{mol}$ photons photosynthetically active radiation (PAR) $\mathrm{m}^{-2} \mathrm{~s}^{-1}$ of cool-white fluorescent light was constant throughout the experiment. Cell numbers were determined using a Zeiss Axiovert microscope at $\times 100$ magnification from well mixed cultures using a Sedgwick Rafter cell counter with a minimum of 200 cells counted per culture.

For lipid experiments, Karlodinium veneficum (Swan River strain) and Amphidinium carterae (CCMP 1314) were grown as per Mooney et al. (2010) on ESAW medium as semi-continuous batch cultures in glass vessels (40 l) with aeration and $\mathrm{CO}_{2}$ bubbling and with $\mathrm{pH}$ regulation ensuring a range of 8.0 to 8.4 . At late exponential growth, after 2 to $4 \mathrm{wk}, 30 \mathrm{l}$ were harvested and the culture was replenished to $40 \mathrm{l}$ with medium. A $12 \mathrm{~h}$ light:12 h dark cycle of $80 \mu \mathrm{mol}$ photons PAR $\mathrm{m}^{-2} \mathrm{~s}^{-1}$ of cool-white fluorescent light was used throughout the experiments.

Reactive oxygen species. Levels of superoxide free radical $\left(\mathrm{O}_{2}^{-}\right)$in 22 species of marine algae were measured using the luciferin analogue 2-methyl6-( $p$-methoxyphenyl)-3,7-dihydroimidazol [1,2-a]pyrazin-3-one (MCLA) method (Oda et al. 1995) using a Berthold Autolumat LB 953 luminometer. MCLA (5 × $\left.10^{-6} \mathrm{M}\right)$ was standardized against superoxide dismutase (SOD) $\left(5 \times 10^{-6} \mathrm{M}\right)$ (Sigma). Solutions of $100 \mu \mathrm{l}$ of $5 \times 10^{-6} \mathrm{M}$ MCLA added to triplicate $2 \mathrm{ml}$ cultures were analysed in triplicate for chemiluminescence at $530 \mathrm{~nm}$ and standardized with the addition of $100 \mu \mathrm{l}$ of superoxide dismutase $\left(5 \times 10^{-6} \mathrm{M}\right)$. Superoxide was generated by periodic addition of $5 \times 10^{-6} \mathrm{M}$ xanthine to 10 to 30 units $\mathrm{l}^{-1}$ of xanthine oxidase in filtered seawater (Oda et al. 1992a,b, 1995, Halliwell \& Gutteridge 1999, Marshall et al. 2003). Superoxide free radicals for fish exposures were generated as described above and measured using a Polarstar Optima plate reader (BMG Labtech) at $530 \mathrm{~nm}$.

Lipid extraction and purification. Filters containing $2.6 \times 10^{10}$ and $3 \times 10^{10}$ cells of Karlodinium veneficum (Swan River strain) and Amphidinium carterae (CCMP 1314), respectively, were extracted following a modified Bligh \& Dyer (1959) method using an initial chloroform: methanol:water (1:2:0.8, v/v/v) single-phase solution. The addition of chloroform and Milli-Q water with a final chloroform:methanol:water ratio of 1:1:0.9 
Table 1. Algal species screened in the present study. See 'Materials and methods' for media: GSe, f/2 and ESAW

\begin{tabular}{|c|c|c|c|c|c|c|}
\hline Species & Authority & $\begin{array}{l}\text { Culture } \\
\text { code }\end{array}$ & $\begin{array}{l}\text { Temp } \\
\left({ }^{\circ} \mathrm{C}\right)\end{array}$ & $\begin{array}{l}\text { Medium } \\
\text { and salinity }\end{array}$ & Source locality & $\begin{array}{l}\text { Isolator } \\
\text { and date }\end{array}$ \\
\hline \multicolumn{7}{|l|}{ Dinophyta } \\
\hline Alexandrium catenella ${ }^{\mathrm{a}}$ & $\begin{array}{l}\text { (Wheldon \& Kofoid) } \\
\text { Balech }\end{array}$ & AC.TRA02 & 17 & GSe28 & $\begin{array}{l}\text { Spring Bay, } \\
\text { Tasmania }\end{array}$ & $\begin{array}{l}\text { C. Bolch, } \\
17.10 .1997\end{array}$ \\
\hline Amphidinium carterae $^{\mathrm{b}}$ & Hulburt & CCMP 1314 & 20 & $\mathrm{f} / 215$ & Falmouth, MA, USA & R. Guillard, 1954 \\
\hline Karenia brevis ${ }^{\mathrm{a}}$ & $\begin{array}{l}\text { (Davis) Hansen \& } \\
\text { Moestrup }\end{array}$ & KBCCMP718 & 20 & GSe28 & Florida, USA & W. Wilson, 1958 \\
\hline Karenia brevisulcata ${ }^{a}$ & $\begin{array}{l}\text { (Chang) Hansen \& } \\
\text { Moestrup }\end{array}$ & KDS.CWD82 & 17 & GSe28 & $\begin{array}{l}\text { Wellington, } \\
\text { New Zealand }\end{array}$ & L. MacEnzie \\
\hline Karenia mikimotoi $^{\mathrm{a}}$ & $\begin{array}{l}\text { (Miyake \& Kominami } \\
\text { ex Oda) Hansen \& } \\
\text { Moestrup }\end{array}$ & KMNZ63 & 17 & $\mathrm{f} / 232$ & New Zealand & $\begin{array}{c}\text { A. Haywood, } \\
1994\end{array}$ \\
\hline \multirow[t]{2}{*}{ Karenia papilionacea ${ }^{\mathrm{a}}$} & \multirow[t]{2}{*}{ Haywood \& Steidinger } & PL01 & 20 & GSe/2 35 & $\begin{array}{l}\text { Port Lincoln, } \\
\text { South Australia }\end{array}$ & $\begin{array}{l}\text { M. de Salas, } \\
2003\end{array}$ \\
\hline & & AB01 & 20 & GSe/2 35 & $\begin{array}{l}\text { Ansons Bay, } \\
\text { Tasmania }\end{array}$ & $\begin{array}{l}\text { M. de Salas, } \\
2003\end{array}$ \\
\hline Karenia umbella & $\begin{array}{l}\text { de Salas, Bolch \& } \\
\text { Hallegraeff }\end{array}$ & KU.PL01 & 20 & GSe/2 35 & $\begin{array}{l}\text { Port Lincoln, } \\
\text { South Australia }\end{array}$ & $\begin{array}{l}\text { M. de Salas, } \\
2002\end{array}$ \\
\hline Karlodinium antarcticum ${ }^{\mathrm{a}}$ & de Salas & KDAN.SO10.1 & 12 & GSe/2 35 & $\begin{array}{l}\text { Southern Ocean } \\
50^{\circ} \mathrm{S}, 145^{\circ} \mathrm{E}\end{array}$ & $\begin{array}{l}\text { M. de Salas, } \\
\text { 16.03.2006 }\end{array}$ \\
\hline Karlodinium australe ${ }^{\mathrm{a}}$ & $\begin{array}{l}\text { de Salas, Bolch \& } \\
\text { Hallegraeff }\end{array}$ & KDA.DE12 & 12 & GSe/2 35 & $\begin{array}{l}\text { Derwent River, } \\
\text { Tasmania }\end{array}$ & $\begin{array}{l}\text { M. de Salas, } \\
27.09 .2006\end{array}$ \\
\hline Karlodinium ballantinum ${ }^{\mathrm{a}}$ & de Salas & KDBM & 17 & $\mathrm{f} / 232$ & $\begin{array}{c}\text { Mercury Passage, } \\
\text { Tasmania }\end{array}$ & $\begin{array}{l}\text { M. de Salas, } \\
01.02 .2006\end{array}$ \\
\hline Karlodinium conicum $^{\mathrm{a}}$ & de Salas & KDCSO15 & 17 & $\mathrm{f} / 232$ & $\begin{array}{l}\text { Southern Ocean } \\
44^{\circ} 41^{\prime} \mathrm{S}, 147^{\circ} 07^{\prime} \mathrm{E}\end{array}$ & $\begin{array}{c}\text { M. de Salas, } \\
01.02 .2006\end{array}$ \\
\hline Karlodinium corrugatum ${ }^{\mathrm{a}}$ & de Salas & KDGEAC07.2 & 17 & $\mathrm{f} / 232$ & $\begin{array}{c}\text { Southern Ocean } \\
44^{\circ} 41^{\prime} \mathrm{S}, 147^{\circ} 07^{\prime} \mathrm{E}\end{array}$ & $\begin{array}{c}\text { M. de Salas, } \\
01.02 .2006\end{array}$ \\
\hline Karlodinium decipiens $\mathrm{s}^{\mathrm{a}}$ & de Salas \& Laza & KDDSB01 & 17 & $\mathrm{f} / 232$ & Spring Bay, Tasmania & $\begin{array}{l}\text { M. de Salas, } \\
\text { 19.05.2005 }\end{array}$ \\
\hline \multirow[t]{3}{*}{ Karlodinium veneficum $^{\mathrm{a}, \mathrm{b}}$} & \multirow[t]{3}{*}{ (Ballantine) Larsen } & KVSR01 & 20 & ESAW 15 & $\begin{array}{c}\text { Swan River, } \\
\text { Western Australia }\end{array}$ & $\begin{array}{l}\text { M. de Salas, } \\
\text { 9.03.2001 }\end{array}$ \\
\hline & & KVHU01 & 20 & ESAW 15 & $\begin{array}{l}\text { Huon River, } \\
\text { Tasmania }\end{array}$ & $\begin{array}{l}\text { M. de Salas, } \\
10.01 .05\end{array}$ \\
\hline & & KVDE01 & 20 & ESAW 15 & $\begin{array}{l}\text { Derwent River, } \\
\text { Tasmania }\end{array}$ & \\
\hline Takayama helix ${ }^{\mathrm{a}}$ & $\begin{array}{l}\text { de Salas, Bolch, } \\
\text { Botes \& Hallegraeff }\end{array}$ & THNWB01 & 16 & GSe/2 35 & $\begin{array}{l}\text { North West Bay, } \\
\text { Tasmania }\end{array}$ & $\begin{array}{c}\text { M. de Salas, } \\
14.05 .2001\end{array}$ \\
\hline Takayama tasmanica ${ }^{a}$ & $\begin{array}{l}\text { de Salas, Bolch \& } \\
\text { Hallegraeff }\end{array}$ & TTPL01 & 19 & GSe/2 35 & $\begin{array}{l}\text { Port Lincoln, } \\
\text { South Australia }\end{array}$ & $\begin{array}{c}\text { M. de Salas, } \\
16.06 .2003\end{array}$ \\
\hline Takayama tuberculata $^{\mathrm{a}}$ & de Salas & TTBSO11.1 & 12 & GSe/2 35 & Southern Ocean & M. de Salas \\
\hline \multirow[t]{2}{*}{ Chattonella marina $^{\mathrm{a}}$} & $\begin{array}{l}\text { (Subrahmanyan) } \\
\text { Hara \& Chihara }\end{array}$ & CM.DE01 & 17 & $\mathrm{f} / 235$ & $\begin{array}{l}\text { Derwent River, } \\
\text { Tasmania }\end{array}$ & M. de Salas \\
\hline & & CM.PL02 & 17 & $\mathrm{f} / 235$ & $\begin{array}{l}\text { Port Lincoln, } \\
\text { South Australia }\end{array}$ & $\begin{array}{c}\text { J. M. LeRoi, } \\
\text { 01.04.1996 }\end{array}$ \\
\hline \multirow[t]{2}{*}{ Heterosigma akashiwo ${ }^{\mathrm{a}}$} & (Hada) Hada & HA.НB01 & 18 & $\mathrm{f} / 235 \mathrm{H}$ & Hideaway Bay, Tasmania & M. de Salas \\
\hline & & HA.PL01 & 18 & $\mathrm{f} / 235$ & $\begin{array}{l}\text { Port Lincoln, } \\
\text { South Australia }\end{array}$ & M. de Salas \\
\hline \multicolumn{7}{|l|}{ Cryptophyta } \\
\hline Rhodomonas maculata $^{\mathrm{a}}$ & $\begin{array}{l}\text { (Butcher) Hill \& } \\
\text { Wetherbee }\end{array}$ & RMCS85 & 20 & $\mathrm{f} / 235$ & Dee Why, Australia & $\begin{array}{c}\text { L. Borowitzka, } \\
\text { 01.01.1978 }\end{array}$ \\
\hline \multicolumn{7}{|l|}{ Haptophyta } \\
\hline Pavlova lutheri ${ }^{\mathrm{a}}$ & (Droop) Green & PVCS23 & 20 & $\mathrm{f} / 235$ & $\begin{array}{c}\text { Halifax, Nova Scotia, } \\
\text { Canada }\end{array}$ & \\
\hline \multicolumn{7}{|l|}{ Prasinophyta } \\
\hline Tetraselmis suecica ${ }^{\mathrm{a}}$ & (Kylin) Butcher & TSCS187 & 20 & $\mathrm{f} / 235$ & Brest, France & A. Dodson \\
\hline $\begin{array}{l}\text { Chlorophyta } \\
\text { Dunaliella tertiolecta }{ }^{\mathrm{a}}\end{array}$ & Butcher & DTCS175 & 20 & $\mathrm{f} / 2$ & & \\
\hline
\end{tabular}


(v/v/v) yielded phase separation. The lower, lipid-containing, chloroform layer was concentrated in vacuo by rotary evaporation and the lipid extract transferred to vials, made to volume with $1 \mathrm{ml}$ chloroform and 10 drops of methanol, and stored at $-20^{\circ} \mathrm{C}$ in the dark. Lipid extracts $(592 \mathrm{mg}$ of $K$. veneficum and approx. $1.6 \mathrm{~g}$ of A.carterae) were applied to a silicic acid column (50 $\mathrm{g}$ of silicic acid in chloroform) and fractions eluted as follows: neutral lipids (chloroform), combined MGDG and DGDG (7:13 ratio of chloroform:acetone), SQDG (sulfoquinovosyldiacylglycerol) (7:1 chloroform: methanol), and phospholipids (1:1 chloroform: methanol) (Yongmanitchai \& Ward 1992). The MGDG and DGDG fraction was further separated on another silicic acid column with $500 \mathrm{ml}$ each of the following ratios of chemicals: 11:9 chloroform:acetone (for MGDG) and 7:13 chloroform: acetone (for DGDG). Purity of fractions was confirmed by TLC-FID (thinlayer chromatography and flame ionization detection) on Iatroscan rods (Iatron Laboratories) using acetone: acetic acid:water in the ratio 100:2:1 (Christie 1982).

Liquid chromatography-mass spectrometry (LCMS) analysis of galactolipids. Galactolipid fractions were injected onto a C8 column (LiChrosphere $125 \times$ $4 \mathrm{~mm}, 5 \mu \mathrm{m}$ bead-size RP-8; Agilent) and subjected to a $1 \mathrm{ml} \mathrm{min}{ }^{-1} 10$ to $95 \%$ methanol:water gradient over 45 min using an Agilent 1100 HPLC. Galactolipid peaks were detected using an Agilent Diode Array Detector (DAD) (Model\#G1315B) with a micro high-pressure flow cell (G1315B\#020, $6 \mathrm{~mm}$ path length, $1.7 \mu \mathrm{l} \mathrm{vol-}$ ume) at a wavelength of $210 \mathrm{~nm}$ (Fig. 1). The eluate from the DAD was split $(10 \%$ to mass spectrometer: $90 \%$ to the fraction collector) using a graduated microsplitter valve (model P-470; Upchurch Scientific). The major portion of the eluate was fed into an Agilent 1100 fraction collector (Model G1364C), while the remaining portion was passed into the electro-spray nozzle of the mass spectrometer (Agilent G1956A SL) for ionization with the following spray chamber conditions using $\mathrm{N}_{2}$ as the drying gas: $10 \mathrm{l} \mathrm{min}^{-1}$ flow rate, 60 psi pressure, $350^{\circ} \mathrm{C}$ temperature, $350 \mathrm{~V}$ fragmentor voltage, and $4000 \mathrm{~V}$ capillary voltage. The fatty acid composition of the collected fractions was determined after hydrolysis and methylation by gas chromatography (GC) as described in the next subsection. A solution of $1 \%$ formic acid in water was added at $0.1 \mathrm{ml} \mathrm{min}^{-1}$ to provide appropriate $\mathrm{pH}$ conditions for positive mode ionization. MGDG (18:2/18:2) was used as a calibration standard, verified by LC-MS (Guella et al. 2003). We observed no MS signal characteristic of amphidinol or karlotoxin in the purified MGDG or DGDG components.

Fatty acid identification. Confirmation of OPA and OTA components of MGDG was performed by sampling $10 \mu \mathrm{l}$ of extract fractions, which were transmethylated using $\mathrm{MeOH}: \mathrm{HCl}: \mathrm{CHCl}_{3}$ at a ratio of 10:1:1

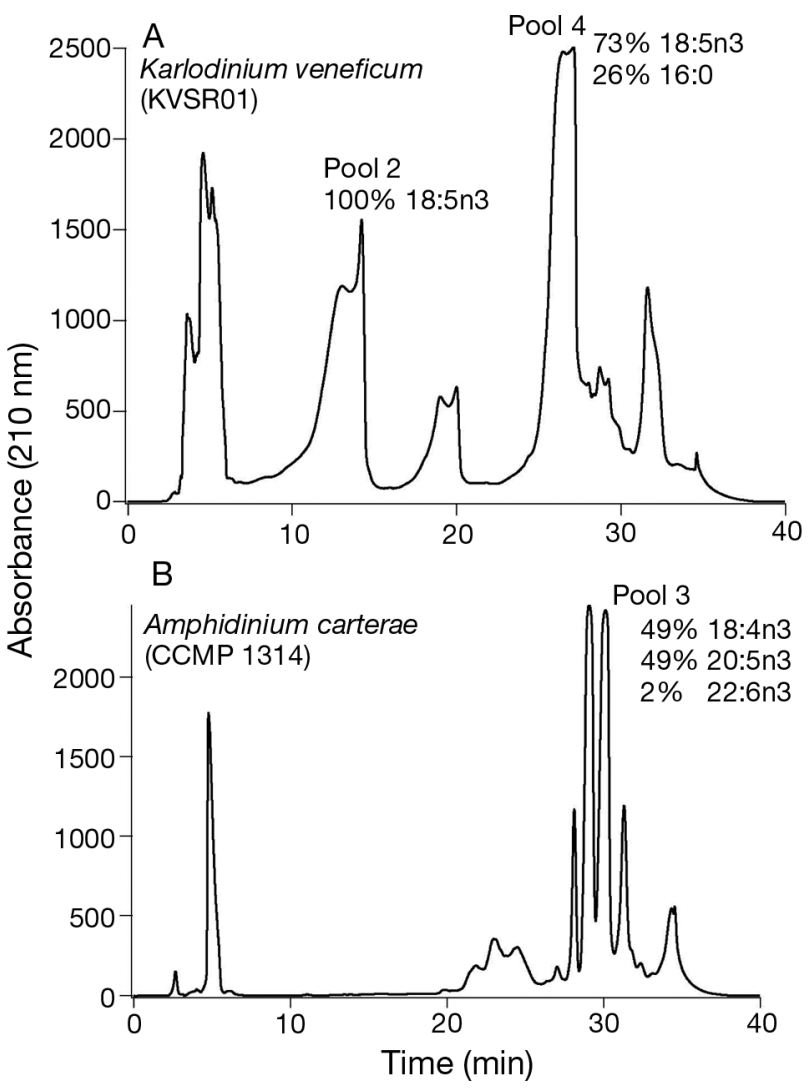

Fig. 1. HPLC chromatograms of galactolipid fractions measured at $210 \mathrm{~nm}$ for (A) octadecapentaenoic acid (OPA)-pure monogalactosyl diglyceride (MGDG) (Pool 2) and OPA-rich MGDG (Pool 4) isolated from Karlodinium veneficum (KVSR01) and (B) octadecatetraenoic acid (OTA)-rich MGDG (Pool 3) isolated from Amphidinium carterae (CCMP 1314). Included are the fatty acid composition, by GC, of each pool

(v/v/v) at $100^{\circ} \mathrm{C}$ for $60 \mathrm{~min}$ and, after the addition of water, extracted 3 times with a 4:1 ratio of hexane:chloroform to yield fatty acid methyl esters (FAME) (Mooney et al. 2007). Samples were made to volume in hexane containing C19:0 and C23:0 internal injection standards and analysed by GC. Identification of FAME was accomplished by comparing gas chromatography retention data with authentic quantitative standards (3B, GLC-68D, GLC-17AA 4 ) from NU-CHECK (Elysian) and qualitative standards from Matreya (Pleasant Gap). Peaks in some samples, including OPA, were also confirmed by GC-MS. The Hewlett-Packard 6890 GC (Agilent) used was equipped with a $30 \mathrm{~m} \times$ $0.25 \mathrm{~mm}$ internal diameter capillary column with $0.25 \mathrm{~mm}$ film thickness (DB Wax; J and W Scientific), and a FID at $300^{\circ} \mathrm{C}$. The GC was run in 'constant flow rate' mode at $1.5 \mathrm{ml} \mathrm{min}^{-1}$ with $\mathrm{H}_{2}$ as the carrier gas. The column-temperature profile was as follows: $50^{\circ} \mathrm{C}$ for $0.5 \mathrm{~min}$, hold at $195^{\circ} \mathrm{C}$ for $15 \mathrm{~min}$ after ramping at

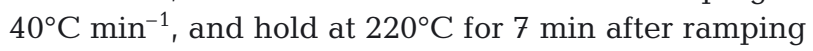


at $2^{\circ} \mathrm{C} \mathrm{min}^{-1}$. Total run time was $38.13 \mathrm{~min}$. The mass of FAME was determined by comparison of the response factor from the FID for each FAME in the quantitative standard (NU-CHECK) and of the internal C19:C21 standards run with each sample. The relative distribution (\% FAME) was calculated based on the peak area of a given peak divided by the total peak area of identified FAME in a sample. OPA-rich and OTA-rich MGDG compositions were identified by comparison with retention time of laboratory standards and published literature (Harvey et al. 1988, Mansour et al. 1999b). The fatty acid composition of the suite of MGDGs and the commercial fatty acids hexadecanoic or palmitic acid (PA) (Sigma) and eicosapentaenoic acid (EPA) (1167, Matreya, LLC) is shown in Table 2; these lipids were tested for ichthyotoxicity and epithelial gill cell line viability.

Fish larvae bioassays. Larvae of the sheepshead minnow Cyprinodon variegatus ( 3 to $5 \mathrm{~d}$ old) maintained at $18^{\circ} \mathrm{C}, 25$ salinity, and $\mathrm{pH} 8.1$ were obtained from Aquatic Biosystems Larvae were acclimated to $20^{\circ} \mathrm{C}$ and either 15 or 32 salinity for $24 \mathrm{~h}$ prior to exposure to lipids and ROS. Larvae were transferred to 12well plates (Falcon, Becton Dickinson) with 3 larvae per well in a total volume of $1 \mathrm{ml}$ water in duplicate wells (6 fish per treatment), and acclimated for $3 \mathrm{~h}$. Larvae were not fed during the experiment. Control experimental larvae were exposed to $1 \mathrm{ml}$ medium (ESAW or f/2) or $10 \mu \mathrm{l}$ methanol (treatments contained lipids dissolved in $10 \mu \mathrm{l}$ methanol). Challenged experimental larvae were exposed to $0.02-120 \mathrm{mg} \mathrm{l}^{-1}$ lipid and/or xanthine-xanthine oxidase. The upper concentration of $120 \mathrm{mg} \mathrm{l}^{-1}$ lipid is equivalent to approximately $5 \times 10^{11}$ cells $\mathrm{l}^{-1}$ based on a total lipid estimation of $0.25 \mathrm{ng}$ per cell. Larvae were observed every $30 \mathrm{~min}$ for the first $6 \mathrm{~h}$ and at $24 \mathrm{~h}$ prior to termination of the experiment, when all fish were preserved in $4 \mathrm{~F} / 1 \mathrm{G}$

Table 2. Summary of fatty acid composition (\%) of lipid treatments on larval sheepshead minnow and rainbow trout gill cells. OPA: octadecapentaenoic acid; OTA: octadecatetraenoic acid; EPA: eicosapentaenoic acid; DHA: docosahexaenoic acid; PA: palmitic acid; MGDG: monogalactosyl diglyceride

\begin{tabular}{|c|c|c|c|c|c|}
\hline \multirow{2}{*}{ Treatment } & \multicolumn{5}{|c|}{ - Fatty acid } \\
\hline & OPA & OTA & EPA & DHA & PA \\
\hline OPA-rich MGDG ${ }^{a, b}$ & 73 & & & & 26 \\
\hline OTA-rich MGDG $^{\mathrm{a}, \mathrm{b}}$ & & 49 & 49 & 2 & \\
\hline OPA-pure MGDG $^{\mathrm{a}}$ & 100 & & & & \\
\hline OTA/EPA MGDGa & 23 & 51 & 26 & & \\
\hline Commercial $\mathrm{PA}^{\mathrm{b}}$ & & & & & 99 \\
\hline Commercial EPA $^{b}$ & & & 99 & & \\
\hline $\begin{array}{l}{ }^{2} \text { Larval sheepshead } \\
{ }^{\mathrm{b}} \text { Gill cell RTgill-W1 }\end{array}$ & innow & reatm & & & \\
\hline
\end{tabular}

preservative (4\% formalin, 1\% glutaraldehyde in phosphate buffered saline) (McDowell \& Trump 1976) and stored for histopathological analysis. Observation of superoxide production from xanthine and xanthine oxidase revealed that $10 \mu \mathrm{l}$ xanthine $\left(5 \times 10^{-6} \mathrm{M}\right)$ and $10 \mu \mathrm{l}$ xanthine oxidase $\left(5 \times 10^{-6} \mathrm{M}\right)$ produced similar levels of superoxide to Kareniaceae cultures in wellplates. Addition of $50 \mu \mathrm{l}$ xanthine $\left(5 \times 10^{-6} \mathrm{M}\right)$ and $50 \mu \mathrm{l}$ xanthine oxidase $\left(5 \times 10^{-6} \mathrm{M}\right)$ generated similar levels of superoxide as Chattonella marina cultures. Larvae were exposed to superoxide (low and high levels) and OPA-rich and OTA-rich MGDG (2 to $120 \mathrm{mg} \mathrm{l}^{-1}$ ) as standalone treatments and in combination.

Gill cell line assay. The rainbow trout (Oncorhynchus mykiss) epithelial gill cell line RTgill-W1 was obtained from the American Type Culture Collection. The cells were grown in $25 \mathrm{~cm}^{2}$ culture-treated flasks in Leibovitz's L-15 medium (L1518, Sigma) supplemented with $10 \%$ (v/v) fetal bovine serum (FBS) (12003C, Sigma) and an antibiotic antimycotic solution (A5955, Sigma) containing penicillin (10 000 units $\left.\mathrm{ml}^{-1}\right)$, streptomycin $\left(10 \mathrm{mg} \mathrm{ml}^{-1}\right)$, and amphotericin B $\left(25 \mu \mathrm{g} \mathrm{ml}^{-1}\right)$, and routinely maintained at $19^{\circ} \mathrm{C}\left( \pm 1^{\circ} \mathrm{C}\right)$ in the dark. Confluent flasks were treated with $0.25 \%$ trypsin with $0.02 \%$ EDTA in Hank's balanced salt solution (59428C, Sigma) for detachment and then counted using a haemocytometer and seeded at a concentration of $2 \times 10^{5}$ cells $\mathrm{ml}^{-1}$ in a final volume of $100 \mu \mathrm{l}$ in quadruplicate in 96-well flat bottomed microplates (3860-096, Iwaki). The gill cells were exposed to OPA-rich and OTA-rich MGDG (0.02 to $120 \mathrm{mg} \mathrm{l}^{-1}$ ) for $60 \mathrm{~h}$ in the dark. These fatty acids were dissolved in $\mathrm{MeOH}$ and mixed with L-15ex medium (Schirmer et al. 1997) for the exposure assays. The final concentration of $\mathrm{MeOH}$ was $1 \%$. The commercial fatty acids PA and EPA were also tested at the same concentrations. Gill cell viability was determined using the indicator dye alamarBlue (DAL1025, Invitrogen) (Pagé et al. 1993, Nakayama et al. 1997). The fluorescence of alamarBlue was detected using excitation and emission filters of 540 and $590 \mathrm{~nm}$, respectively, in a microplate reader (FLUOstar OPTIMA, BMG Labtech). The results are expressed as a percentage of the readings compared to the controls. A more detailed account of the gill cell line bioassays can be found in Dorantes-Aranda et al. (2011).

\section{RESULTS}

\section{Lipid ichthyotoxicity to sheepshead minnow larvae}

Purified lipids, OPA-rich MGDG, and OTA-rich MGDG (Table 2) were added to fish larvae in wells at concentrations ranging from 0.02 to $120 \mathrm{mg} \mathrm{l}^{-1}$. No fish 
mortalities were observed in all treatments and at all concentrations. Above $1 \mathrm{mg} \mathrm{l^{-1 }}$ of OPA-rich MGDG and OTA-rich MGDG, fish were visibly affected: sluggish swimming and, as the concentration increased, gulping at the surface, inability to maintain an upright position in the water column, and delayed movements occurred. No mortalities, however, were observed in either treatment after $24 \mathrm{~h}$. Similarly, no fish mortalities were observed in control treatments.

\section{Lipid cytotoxicity on RTgill-W1}

Most of the fatty acids had a negative effect on the gill cells, except for OPA-pure MGDG, which contrary to expectation had a positive effect on the gill cells. Viability increased by 10 and $17 \%$ during the first $24 \mathrm{~h}$ when exposed to 20 and $120 \mathrm{mg} \mathrm{l}^{-1}$, respectively (Fig. $2)$. However, the combination of OPA (73\%) and PA $(26 \%)$ in OPA-rich MGDG exhibited a significant toxic effect, but only at a high concentration of $120 \mathrm{mg} \mathrm{l}^{-1}$ ( $\alpha=0.05$ ) (Fig. 3A). This toxic effect was time-dependent with maximum toxicity after $60 \mathrm{~h}$ and cell viability reduced to $55.4 \%$. A commercial preparation of palmitic free fatty acid (Table 2) had a similar effect at $120 \mathrm{mg} \mathrm{l}^{-1}$, except for the effect being more gradual and with cell damage increasing with concentration and time of exposure (Fig. 3B). OTA-rich MGDG showed both a time- and concentration-dependent effect (Fig. 3C). The highest and fastest toxicity was registered in combinations where EPA was present, especially at high concentrations of EPA. In the mixture containing $26 \%$ of EPA, the gill cells were $99.8 \%$ viable during the first $12 \mathrm{~h}$ of exposure to $120 \mathrm{mg} \mathrm{l}^{-1}$,

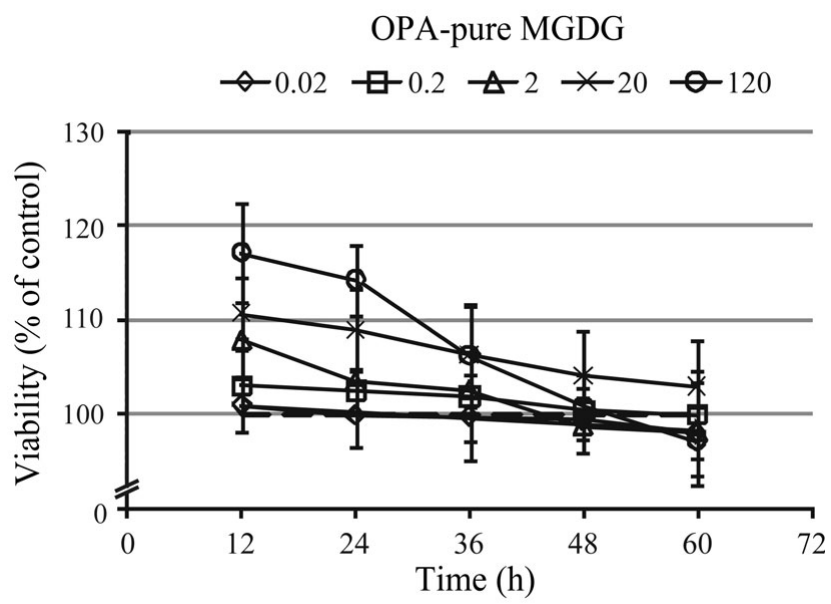

Fig. 2. Effect of octadecapentaenoic acid (OPA)-pure monogalactosyl diglyceride (MGDG) on rainbow trout gill cells (RTgill-W1) at 0.02 to $120 \mathrm{mg} \mathrm{l}^{-1}$ (presented as percent viability compared to controls, mean $\pm \mathrm{SD}, \mathrm{n}=4$ ) but viability decreased to $19.9 \%$ in combination with $47 \%$ EPA (Fig. 3B). Combination with $5 \%$ of EPA did not show high toxicity, with the gill cells only losing $10 \%$ viability during $60 \mathrm{~h}$ exposure at the highest concentration of $120 \mathrm{mg} \mathrm{l}^{-1}$. Toxicity of EPA was confirmed when using a commercial preparation, which produced the highest loss (from $\sim 40$ down to $1.5 \%$ ) of gill cell viability observed in this study when exposed to $120 \mathrm{mg} \mathrm{l}^{-1}$ of $100 \%$ EPA for 12 and $60 \mathrm{~h}(\alpha=0.05)$, respectively (Fig. 3D).

\section{ROS production and ichthyotoxicity and cytotoxicity}

Superoxide production per cell by 15 species of Kareniaceae ranged from 1 to 22 cellular chemiluminescence units (CCU) compared to 100 to $110 \mathrm{CCU}$ by 2 strains of Chattonella marina (Fig. 4). The highest cellular production of superoxide in Kareniaceae was recorded in Takayama species (17 to $22 \mathrm{CCU})$, and the lowest was observed in the 3 strains of Karlodinium veneficum (from Swan River, Derwent River, and Huon River; see Table 1), Karlodinium decipiens, and Karlodinium ballantinum (1 CCU). Non-toxic aquaculture feed algae, Dunaliella tertiolecta, Pavlova lutheri, and Tetraselmis suecica all recorded low cellular superoxide production (1 CCU). Isolates of the same species, Karenia papilionacea (2 strains), Karlodinium veneficum (3 strains) and C.marina (2 strains) produced comparable cellular superoxide levels. Exposure of larval finfish to the equivalent of low and high levels of superoxide (20 and $100 \mathrm{CCU}$, respectively), from periodic addition of xanthine and xanthine oxidase, did not result in mortalities. Slower swimming was observed, but no symptoms corresponding to gill insult (mucus production or epithelial gill lifting) occurred. Similarly, no fish mortalities were observed in control treatments. Synthetically produced ROS, using 5 to $25 \mu \mathrm{M}$ xanthine and $30 \mathrm{U} \mathrm{l}^{-1}$ of xanthine oxidase on gill cells from rainbow trout, resulted in only minor $(<14 \%)$ loss of viability of rainbow trout gill cells (Fig. 5).

\section{Synergistic ichthyotoxicity}

No fish mortalities were observed upon exposure to low and high superoxide and treatments with lipids, OPA-rich, and OTA-rich MGDG at 0.02 to $120 \mathrm{mg} \mathrm{l}^{-1}$, after $24 \mathrm{~h}$ exposure. Above $20 \mathrm{mg} \mathrm{l}^{-1}$ of OPA-rich MGDG and OTA-rich MGDG combined with low or high superoxide treatments, fish were visibly affected, with gulping at the surface and difficulty swimming upright; however, no mortalities were observed in either treatment after $24 \mathrm{~h}$ exposure. 

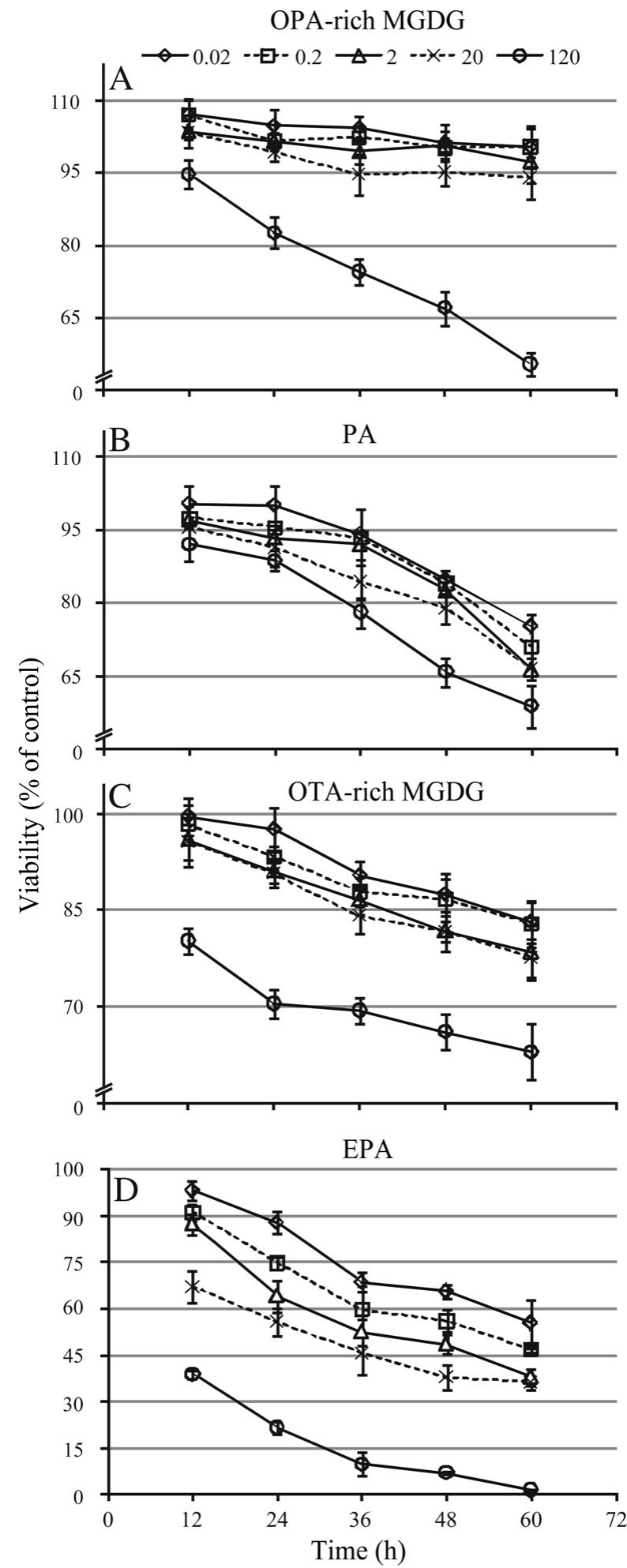

Fig. 3. Exposure of rainbow trout gill cells (RTgill-W1) to (A) octadecapentaenoic acid (OPA)-rich monogalactosyl diglyceride (MGDG), (B) commercial palmitic acid (PA), (C) octadecatetraenoic acid (OTA)-rich MGDG and (D) commercial eicosapentaenoic acid (EPA) at 0.02 to $120 \mathrm{mg} \mathrm{l}^{-1}$ (presented as percent viability compared to controls, mean $\pm \mathrm{SD}$,

$$
\mathrm{n}=4 \text { ) }
$$

\section{DISCUSSION}

PUFAs

The hemolytic, antibacterial, and anti-algal activity of PUFAs (Ikawa 2004) are well-documented; however, the fish-killing ability of these molecules remains controversial.

Hemolytic activity by the raphidophyte Fibrocapsa japonica, in the presence of PUFAs, increased with light intensity (de Boer et al. 2009), and analyses of hemolytic fractions from Karenia mikimotoi have previously confirmed that OPA was present (Yasumoto et al. 1990, Arzul et al. 2000).

Many toxic and non-toxic algae contain OPA, a PUFA found primarily as a mono- or digalactosyl glycolipid in the chloroplast (Leblond \& Lasiter 2009). Experiments with toxic $\left(\mathrm{LC}_{50}\right.$ at $4 \times 10^{3}$ cell ml-1 ${ }^{-1}$ and nontoxic (no mortality up to $4 \times 10^{5} \mathrm{cell} \mathrm{ml}^{-1}$ ) strains of the haptophyte Chrysochromulina polylepis, both of which contained OPA (16 and 19\%, respectively), suggested another causative agent was responsible for brine shrimp toxicity (John et al. 2002). PUFA ichthyotoxicity against fry of the fathead minnow Pimephales promelas from another haptophyte, Prymnesium parvum, suggests increasing potency with increasing fatty acid chain length and degree of unsaturation; however, this does not fully account for naturally occuring fish killing blooms of this species (Henrikson 2010).

Our exposure of sheepshead minnow larvae for $24 \mathrm{~h}$ to high concentrations of OPA-rich MGDG caused sluggish swimming and gulping but no mortality even at concentrations up to $120 \mathrm{mg} \mathrm{l}^{-1}$. Inactivity of OPArich MGDG was found at $50 \mu \mathrm{g} \mathrm{ml}^{-1}$ in vitro against leukemia cells L-1210 and P-338 (Oshima et al. 1994) (Table 3). Conversely, cytolytic activity of OPA-rich MGDG and OPA-OTA-rich MGDG against heart cells of oysters was found at concentrations $>0.5 \mu \mathrm{g} \mathrm{l}^{-1}$ using bioassay-guided fractionation (Hiraga et al. 2002).

Experiments using synthetic OPA have confirmed toxicity to sea bass (Sola et al. 1999) and trout hepatocytes (Fossat et al. 1999) (Table 3). The toxicity of synthetic OPA to the dinoflagellate Karenia mikimotoi itself was also demonstrated, but to a lesser extent than against other algae, and has been proposed as a factor in causing dominance of $K$. mikimotoi biomass in the pycnocline layer (Gentien et al. 2007). Levels of intracellular free fatty acid in 8 species of Kareniaceae cultures were between 2 and $11 \%$ of total lipid, with K. mikimotoi at 7.5\% (Mooney et al. 2007) and $8 \%$ (Parrish et al. 1993). The latter workers found only 1 and $2 \%$ of toxic OPA and EPA, respectively, in extracellular media, which suggests that PUFAs are shortlived in culture media and the water column (Jüttner 2001). 


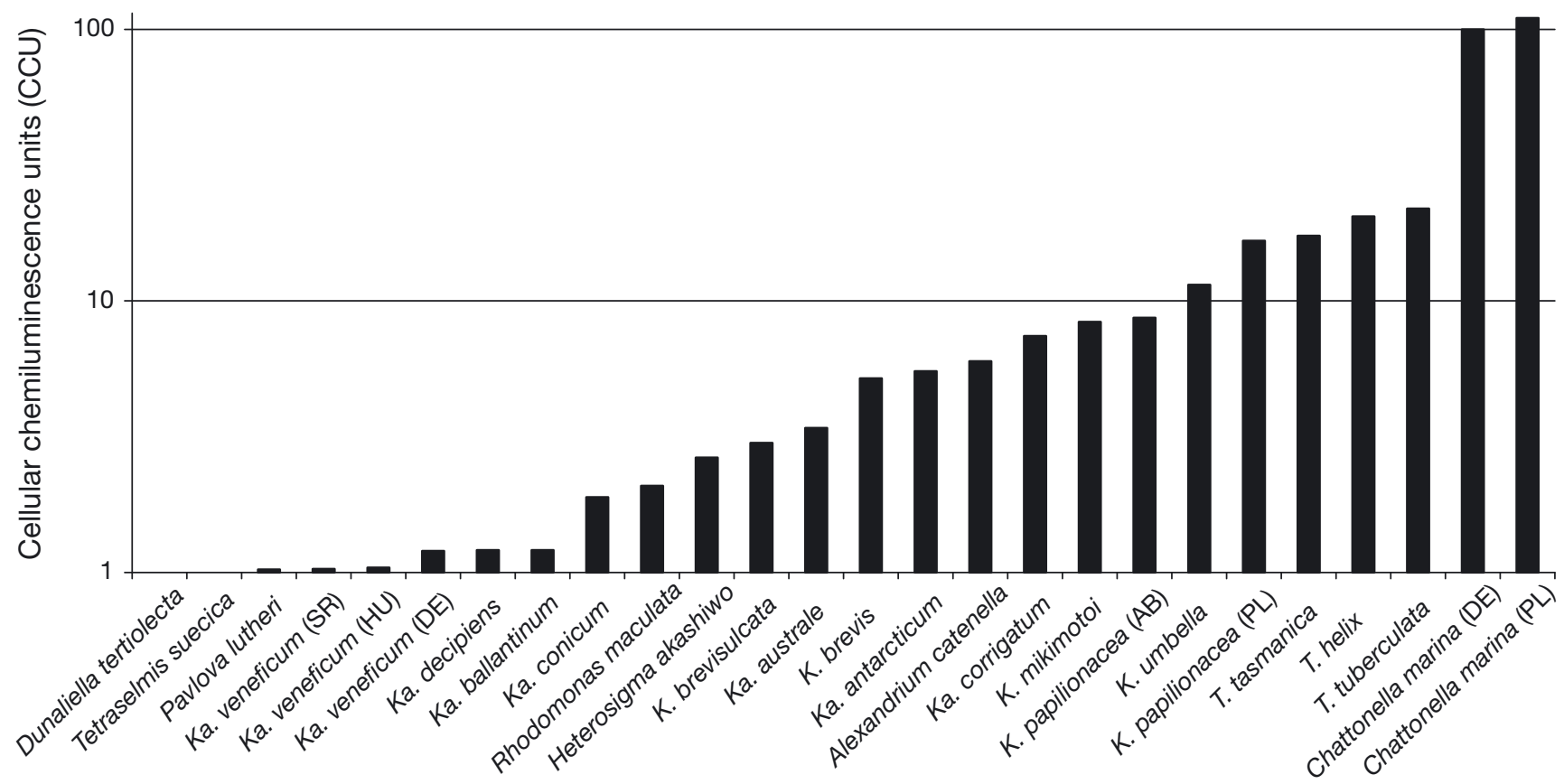

Fig. 4. Superoxide production in 22 species of marine algae expressed as cellular chemiluminescence units (CCU). $K$. $=$ Karenia, Ka. = Karlodinium, T. = Takayama. Strains are indicated in brackets after species (see Table 1): SR = Swan River, HU = Huon River, $\mathrm{DE}=$ Derwent River, $\mathrm{AB}=$ Ansons Bay, PL = Port Lincoln

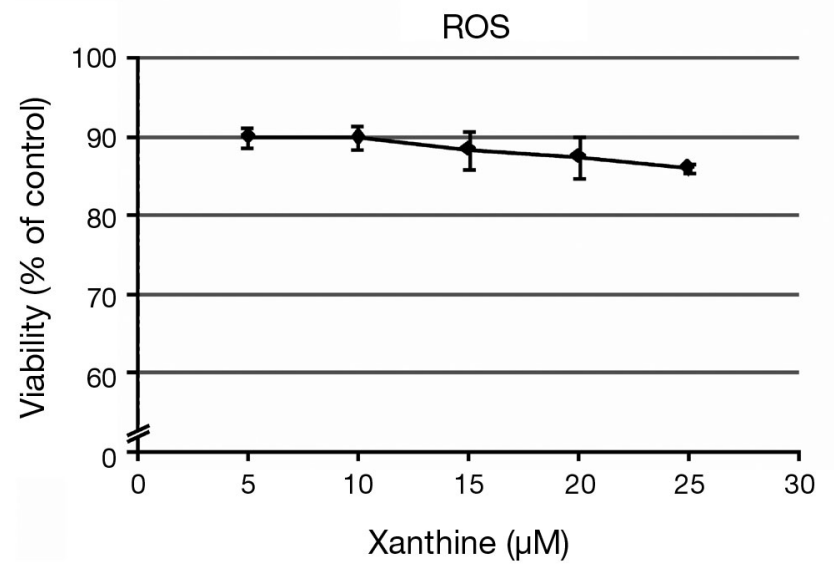

Fig. 5. Influence of reactive oxygen species (ROS), as synthetically produced superoxide using 5 to $25 \mu \mathrm{M}$ xanthine and $30 \mathrm{U} \mathrm{l}^{-1}$ of xanthine oxidase, on rainbow trout gill cells (RTgillW1) (presented as percent viability compared to controls, mean $\pm \mathrm{SD}, \mathrm{n}=4)$

The rainbow trout gill cell line RTgill-W1 was much more sensitive to PUFAs harvested from the dinoflagellates Karlodinium veneficum and Amphidinium carterae than intact sheepshead minnow fish larvae (Table 3). In our work, the OPA-pure MGDG fraction was nontoxic to sensitive rainbow trout gill cell lines and even improved cell viability. This may be due to the ability of the gill cells to metabolize certain fatty acids, as demonstrated previously with cultured fish cells (Ghioni et al. 2001). Surprisingly, a commercial preparation of the saturated free fatty acid PA caused significant fish gill cell damage (40\% viability loss in $60 \mathrm{~h}$ ). PA has been previously demonstrated to cause cell death of human melanoma cell lines (de Sousa Andrade et al. 2005), and the loss of viability from exposure to the OPA-rich MGDG (73\% OPA and $26 \%$ PA) preparation in our work is therefore almost certainly caused by PA. The apparent toxic mechanism of PA exposure is loss of membrane integrity and/or DNA fragmentation, as observed in hamster lung cells exposed to $\mathrm{PA}_{\text {; }}$ a large amount of triacylglycerol accumulated in these lung cells which caused cytoplasmic clefts and perturbed cell functions and caused cell injury (Urade \& Kito 1982). Contradictory literature claims as to the ichthyotoxicity of OPA (in our work nontoxic to sheepshead minnow larvae and RTgill-W1 cells) may be due to the presence of byproducts in previous studies. As previously acknowledged by Yasumoto et al. (1990), oxidation artifacts can be generated in water samples by being frozen and thawed for lipid extraction, in purified hemolytic fractions of PUFA-rich MGDG, DGDG, and also in the preparation of the free fatty acid OPA.

OTA and EPA have been previously claimed to cause hemolysis (Fu et al. 2004, de Boer et al. 2009) and lipid peroxidation. EPA has been claimed to exhibit a synergistic effect with reactive oxygen species, most likely producing toxic lipid peroxidation byproducts and hence faster mortality of fish (Marshall et al. 2003). In the present work, loss of gill cell 
Table 3. Comparative biological activity of octadecapentaenoic acid (OPA), octadecatetraenoic acid (OTA), eicosapentaenoic acid (EPA) and reactive oxygen species (ROS). For fatty acid concentration of monogalactosyl diglyceride (MGDG) treatments see Table 2. CCU: cellular chemiluminescence units, TCU : total chemiluminescence units; $\mathrm{IC}_{50}$ : half maximal (50\%) inhibitory concentration of an antagonistic substance; comparable to $\mathrm{EC}_{50}$ for agonistic substances; $\mathrm{LD}_{50}$ : lethal dose which kills $50 \%$ of exposed test animals (or $25 \%$ for $\mathrm{LD}_{25}$ ); $\mathrm{EC}_{50}$ : median effective concentration

\begin{tabular}{|c|c|c|c|c|}
\hline Chemical & Bioassay & $\begin{array}{c}\text { Concentration } \\
\left(\mathrm{mg} \mathrm{l}^{-1}\right)\end{array}$ & Toxicity & Source \\
\hline \multicolumn{5}{|l|}{ Galactolipids } \\
\hline OPA-pure MGDG & Rainbow trout gill cells RTgill-W1 & $0.2-120$ & None & Present study \\
\hline \multirow[t]{5}{*}{ OPA-rich MGDG } & Sheepshead minnow larvae & $0.2-120$ & None & Present study \\
\hline & Rainbow trout gill cells RTgill-W1 & $0.02-20$ & None & Present study \\
\hline & Rainbow trout gill cells RTgill-W1 & 120 & $45 \%$ viability loss in $60 \mathrm{~h}$ & Present study \\
\hline & Leukemia cells L-1210, P-338 & 50 & None & Oshima et al. (1994) \\
\hline & Heart cells of oysters & $>0.5$ & Cytolytic & Hiraga et al. (2002) \\
\hline \multirow[t]{2}{*}{ OPA-OTA rich MGDG } & Heart cells of oysters & $>0.5$ & Cytolytic & Hiraga et al. (2002) \\
\hline & Rainbow trout gill cells RTgill-W1 & 120 & $23 \%$ viability loss after $60 \mathrm{~h}$ & Present study \\
\hline \multirow{3}{*}{ OTA-rich MGDG } & Sheepshead minnow larvae & $0.21-120$ & None & Present study \\
\hline & Rainbow trout gill cells RTgill-W1 & $0.02-20$ & $17-22 \%$ viability loss & Present study \\
\hline & Rainbow trout gill cells RTgill-W1 & 120 & $37 \%$ viability loss in $60 \mathrm{~h}$ & Present study \\
\hline \multicolumn{5}{|l|}{ Free fatty acids } \\
\hline \multirow[t]{4}{*}{ OPA } & Sea bass gill (ATPase activity) & 0.16 & $\mathrm{IC}_{50}$ & Sola et al. (1999) \\
\hline & Trout hepatocytes (ATPase activity) & 0.866 & $\mathrm{IC}_{50}$ & Fossat et al. (1999) \\
\hline & Karenia mikimotoi & 0.15 & $\mathrm{LD}_{50}$ & Gentien et al. (2007) \\
\hline & Diatom growth & 1 & Inhibit & Gentien et al. (1998) \\
\hline \multirow[t]{2}{*}{ OTA } & Damselfish & 25 & $\mathrm{LD}_{25}$ & Marshall et al. (2003) \\
\hline & Hemolytic & 25 & $\mathrm{EC}_{50}$ & de Boer et al. (2009) \\
\hline \multirow[t]{2}{*}{ PA } & Rainbow trout gill cells RTgill-W1 & 0.02 & $25 \%$ viability loss & Present study \\
\hline & Rainbow trout gill cells RTgill-W1 & 120 & $40 \%$ viability loss & Present study \\
\hline \multirow[t]{8}{*}{ EPA } & Zooplankton & 10 & $\mathrm{LC}_{50}$ & Jüttner (2001) \\
\hline & Damselfish & 2.7 & $\mathrm{LD}_{50}$ & Marshall et al. (2003) \\
\hline & Artemia & $50 \mu \mathrm{g} \mathrm{ml}^{-1}$ & $80 \%$ mortality & Pezzolesi et al. (2010) \\
\hline & Diatom & 1.5 & & Arzul et al. (1998) \\
\hline & Hemolytic & 4 & $\mathrm{EC}_{50}$ & de Boer et al. (2009) \\
\hline & Rainbow trout gill cells RTgill-W1 & 0.02 & $44 \%$ viability loss & Present study \\
\hline & Rainbow trout gill cells RTgill-W1 & 20 & $64 \%$ viability loss & Present study \\
\hline & Rainbow trout gill cells RTgill-W1 & 120 & $98.5 \%$ viability loss in $60 \mathrm{~h}$ & Present study \\
\hline \multicolumn{5}{|l|}{ Reactive oxygen species } \\
\hline \multirow[t]{3}{*}{ Synthetic ROS } & Damselfish & $100 \mathrm{CCU}$ & None & Marshall et al. (2003) \\
\hline & Sheepshead minnow larvae & $100 \mathrm{CCU}$ & None & Present study \\
\hline & Rainbow trout gill cells RTgill-W1 & $\begin{array}{c}57 \times 10^{4} \\
\text { TCU }^{\mathrm{a}}\end{array}$ & $10-14 \%$ viability loss in $2 \mathrm{~h}$ & Present study \\
\hline
\end{tabular}

viability was observed in all 4 combinations of fatty acids containing OTA, EPA, or both. When co-occurring, a higher loss of viability was observed (up to $37 \%$ ), suggesting a magnified toxic effect. The present work confirms the harmful effects of the fatty acids OTA, EPA, and PA. Commercial preparations of EPA and PA also supported claimed toxicity to fish gill cells.

\section{ROS}

Levels of production of superoxide by Kareniaceae are 10-fold less than known high superoxide producers such as Chattonella marina. The absence of sheepshead minnow larval finfish mortality and absence of impact on rainbow trout gill cell lines exposed to xanthine or xanthine oxidase agrees with observations by Marshall et al. (2003) on damselfish, Acanthochromis polycanthus. The measurement of superoxide by the MCLA method is potentially influenced by other ROS, such as hydrogen peroxide and the hydroxyl radical, as reaction of these ROS with MCLA results in generation of additional superoxide radicals (Kambayashi \& Ogino 2003, Wardman 2007). In our work, we observed no mortality of sheepshead minnow larvae exposed to superoxide and OPA-rich MGDG or OTA-rich MGDG, at high lipid and superoxide concentrations. Our results differ from those of Marshall et al. (2003), where EPA toxicity increased 3fold in conjunction with superoxide. These differences may be attributable to the form of fatty acid used (FFA versus MGDG), the type of PUFA (EPA versus OPA or OTA), the fish species (damselfish versus sheepshead minnow), or fish maturity (adult versus larvae). 
Damselfish $\mathrm{LD}_{50}$ toxicity of the free acid EPA was $2.7 \mathrm{mg} \mathrm{l}^{-1}$, whereas only $25 \%$ of fish died with free OTA (referred to as stearidonic acid) at $25 \mathrm{mg} \mathrm{l}^{-1}$ (Marshall et al. 2003), indicating vast differences in PUFA activity (Table 3).

\section{CONCLUSIONS}

The observed difference in activity of PUFAs as membrane lipids (as glycolipids) compared to synthetic or purified forms (as FFA or FAME) suggests that additional components or by-products are responsible, which potentially could be introduced during preparation or storage of fatty acids. PUFAs are stable against peroxidation in aqueous systems (Miyashita et al. 1993), whereas those preserved in organic solvents such as chloroform and hexane are more easily oxidized (Halliwell \& Gutteridge 1999). PUFAs, EPA, and DHA, are claimed to have anti-oxidant properties, making synergistic ichthyotoxic activity with ROS unlikely (Okuyama et al. 2008).

Rupturing of algal cells and the release of reactive lipids combined with superoxide and contact with sensitive fish gills has been proposed, in the absence of a known toxin, as a possible mechanism of killing fish (Okaichi 1983), including lipids present in the free fatty acid form (Marshall et al. 2003). Many Kareniaceae contain high relative levels of OPA (14 to $35 \%$ ) and DHA (8 to $23 \%$ ) (Mooney et al. 2007); however, not all these dinoflagellate species are implicated in fish kills. Similarly, toxic and non-toxic strains of the haptophyte Chrysochromulina polylepis containing 16 to $19 \%$ OPA indicate that these fatty acids are not responsible for brine shrimp toxicity (John et al. 2002).

The gill cell line RTgill-W1 has proved to be a promising new tool for ichthyotoxic assessment of fishkilling microalgae. Scanning and transmission electron microscopy confirmed membrane disruption of gill cells after exposure to Chattonella marina and PA (Dorantes-Aranda et al. 2011). This supports claims that gills are a potential target organ for ichthyotoxic compounds from harmful microalgae. In the present study, sheepshead minnow larvae were not affected by fatty acids, while gill cells were. This suggests that for fish to be impacted by fatty acids their gills need to be well developed. Deeds et al. (2006) also found that juvenile sheepshead minnow were more sensitive to karlotoxin than were larvae. The application of RTgill-W1 has much more ecological relevance than using mammalian cells or brine shrimp.

Synergistic interactions between free fatty acids and reactive oxygen species as claimed for raphidophytes could not be confirmed. Gill cell damaging effects from EPA and OTA (but not OPA) were conclusively demon- strated, however, and remain candidates of ichthyotoxicity when well-defined toxins such as brevetoxin or karlotoxin can be ruled out as causative factors. The rainbow trout gill cell viability bioassay results are in agreement with observed symptoms and mortalities of sheepshead minnow larvae. Further work using the gill cell line will ascertain closer relationships between loss of viability and lethal dose and concentration to fish.

Acknowledgements. This paper is dedicated to the pioneering work on PUFA ichthyotoxicity by the late Dr. Patrick Gentien. The work represents part of the PhD work of B.D.M. and J.J.D.-A. and was supported by Australian Research Council Discovery Projects DP0557820 and DP0880298. We thank $\mathrm{H}$. Bond at the School of Plant Science, University of Tasmania, for culturing assistance. From the UMBI Center of Marine Biotechnology N. Krupatkina provided advice on fish bioassays. B.D.M. acknowledges the support of the AustralianAmerican Fulbright Commission as the Inaugural Tasmanian Fulbright Scholar. This paper is partially a result of research funded by the National Oceanic and Atmospheric Administration Coastal Ocean Program under award \#NA04NOS4780276 to University of Maryland Biotechnology Institute and Grant \# U50/CCU 323376, Centers for Disease Control and Prevention and the Maryland Department of Health and Mental Hygiene. The authors also thank G. Woods, C. Tovar, and R. Gasperini from the Menzies Research Institute, University of Tasmania, for technical and facilities support for the gill cell line assays, and D. Evans and V. Hecht from the School of Plant Science, University of Tasmania, for facilities support. J.J.D.-A. was financed by the fellowships CONACyT 190179 and DGRI-SEP.

\section{LITERATURE CITED}

Adolf JE, Place AR, Stoecker DK, Harding LW Jr (2007) Modulation of polyunsaturated fatty acids in mixotrophic Karlodinium veneficum (Dinophyceae) and its prey, Storeatula major (Cryptophyceae). J Phycol 43:1259-1270

Andersen RA, Morton SL, Sexton JP (1997) Provasoli-Guillard National Center for Culture of Marine Phytoplankton 1997 list of strains. J Phycol 33(Suppl.):1-75

Arzul G, Gentien P, Bodennec F (1998). Potential toxicity of microalgal polyunsaturated fatty acids (PUFAs). In: Baudimant G, Guézennec JH, Roy P, Samain JF (eds) Marine lipids. IFREMER, Plouzané, p 53-62

Bell MV, Dick JR, Pond DW (1997) Octadecapentaenoic acid in a raphidophyte alga, Heterosigma akashiwo. Phytochemistry 45:303-306

- Berges JA, Franklin DJ, Harrison PJ (2001) Evolution of an artificial seawater medium: improvements in enriched seawater, artificial water over the last two decades. J Phycol 37:1138-1145

Blackburn SI, Hallegraeff GM, Bolch CJS (1989) Vegetative production and sexual life cycle of the toxic dinoflagellate Gymnodinium catenatum from Tasmania, Australia. J Phycol 25:577-590

Bligh EG, Dyer WJ (1959) A rapid method of total lipid extraction and purification. Can J Biochem Physiol 37:912-917

Christie WW (1982). Lipid analysis.Pergamon Press, Oxford

de Boer MK, Tyl MR, Fu M, Kulk G and others (2009) Haemolytic activity within the species Fibrocapsa japonica (Raphidophyceae). Harmful Algae 8:699-705 
de Sousa Andrade LN, Martins de Lima T, Curi R, de Lauro Castrucci AM (2005) Toxicity of fatty acids on murine and human melanoma cell lines. Toxicol In Vitro 19:553-560

Deeds JR, Reimschuessel R, Place AR (2006) Histopathological effects in fish exposed to the toxins from Karlodinium micrum (Dinophyceae). J Aquat Anim Health 18:136-148

Dorantes-Aranda JJ, Waite TD, Godrant A, Rose AL, Tovar CD, Woods GM, Hallegraeff GM (2011) Novel application of a fish gill cell line assay to assess ichthyotoxicity of harmful marine microalgae. Harmful Algae

Fossat B, Porthé-Nibelle J, Sola F, Masoni A, Gentien P, Bodennec G (1999) Toxicity of fatty acid 18:5n3 from Gymnodinium cf. mikimotoi: II. intracellular $\mathrm{pH}$ and $\mathrm{K}^{+}$ uptake in isolated trout hepatocytes. J Appl Toxicol 19:275-278

Fu M, Koulman A, van Rijssel M, Lützen A, de Boer MK, Tyl MR, Liebezeit G (2004) Chemical characterisation of three haemolytic compounds from the microalgal species Fibrocapsa japonica (Raphidophyceae). Toxicon 43:355-363

Gentien P (1998) Bloom dynamics and ecophysiology of the Gymnodinium mikimotoi species complex. In: Andersen DM, Cembella AD, Hallegraeff GM (eds) Physiological ecology of harmful algal blooms. Springer-Verlag, Berlin, NATO ASI Series, G 41, p 155-173

Gentien P, Lunven M, Lazure P, Youenou A, Crassous MP (2007) Motility and autotoxicity in Karenia mikimotoi (Dinophyceae). Philos Trans R Soc Lond B 362:1937-1946

Ghioni C, Porter AEA, Sadler IH, Tocher DR, Sargent JR (2001) Cultured fish cells metabolize octadecapentaenoic acid (all-cis $\delta 3,6,9,12,15-18: 5)$ to octadecatetraenoic acid (all-cis $\delta 6,9,12,15-18: 4$ ) via its 2 -trans intermediate (trans $\delta 2$, all-cis $\delta 6,9,12,15-18: 5)$. Lipids 36:145-153

Guella G, Frassanito R, Mancini I (2003) A new solution for an old problem: the regiochemical distribution of the acyl chains in galactolipids can be established by electrospray ionisation tandem mass spectrometry. Rapid Commun Mass Spectrom 17:1982-1994

Halliwell B, Gutteridge JMC (1999). Free radicals in biology and medicine. Oxford University Press, Oxford

Harvey HR, Bradshaw SA, O'Hara SCM, Eglington G, Corner EDS (1988) Lipid composition of the marine dinoflagellate Scrippsiella trochoidea. Phytochemistry 27:1723-1729

Henrikson JC, Gharfeh MS, Easton AC, Easton JD and others (2010) Reassessing the ichthyotoxin profile of cultured Prymnesium parvum (golden algae) and comparing it to samples collected from recent freshwater bloom and fish kill events in North America. Toxicon 55:1396-1404

- Hiraga Y, Kaku K, Omoda D, Sugihara K, Hosoya H, Hino M (2002) A new digalactosyl diacylglycerol from a cultured marine dinoflagellate Heterocapsa circularisquama. J Nat Prod 65:1494-1496

Ikawa M (2004) Algal polyunsaturated fatty acids and effects on plankton ecology and other organisms. UNH Cent Freshw Biol Res 6:17-44

> John U, Tillmann U, Medlin LK (2002) A comparative approach to study inhibition of grazing and lipid composition of a toxic and non-toxic clone of Chrysochromulina polylepis (Prymnesiophyceae). Harmful Algae 1:45-57

> Jüttner F (2001) Liberation of 5,8,11,14,17-eicosapentaenoic acid and other polyunsaturated fatty acids from lipids as a grazer defense reaction in epilithic diatom biofilms. J Phycol 37:744-755

Kambayashi Y, Ogino K (2003) Reestimation of Cyprina luciferin analogs (MCLA) as a chemiluminescence probe to detect active oxygen species - cautionary note for use of MCLA. J Toxicol Sci 28:139-148

Kim CS, Lee SG, Lee CK, Kim HG, Jung J (1999) Reactive oxygen species as causative agents in the ichthyotoxicity of the red tide dinoflagellate Cochlodinium polykrikoides. J Plankton Res 21:2105-2115

Kim D, Oda T, Muramatsu T, Kim D, Matsuyama Y, Honjo T (2002) Possible factors responsible for the toxicity of Cochlodinium polykrikoides, a red tide phytoplankton. Comp Biochem Physiol C 132:415-423

Leblond JD, Chapman PJ (2000) Lipid class distribution of highly unsaturated long chain fatty acids in marine dinoflagellates. J Phycol 36:1103-1108

> Leblond JD, Lasiter AD (2009) Mono- and digalactosyldiacylglycerol composition of dinoflagellates. II. Lepidodinium chlorophorum, Karenia brevis and Kryptoperidinium foliaceum, three dinoflagellates with aberrant plastids. Eur J Phycol 44:199-205

Mansour MP, Volkman JK, Jackson AE, Blackburn SI (1999b) The fatty acid and sterol composition of five marine dinoflagellates. J Phycol 35:710-720

Marshall JA, Hovenden M, Oda T, Hallegraeff GM (2002) Photosynthesis does influence reactive oxygen species production in the red tide alga Chattonella marina (Raphidophyceae). J Plankton Res 24:1231-1236

> Marshall JA, Nichols PD, Hamilton B, Lewis RJ, Hallegraeff GM (2003) Ichthyotoxicity of Chattonella marina (Raphidophyceae) to damselfish (Acanthochromis polycanthus): the synergistic role of reactive oxygen species and free fatty acids. Harmful Algae 2:273-281

Marshall JA, Ross T, Pyecroft S, Hallegraeff G (2005a) Superoxide production by marine microalgae. II. Towards understanding ecological consequences and possible functions. Mar Biol 147:541-549

> Marshall JA, Salas M, Oda T, Hallegraeff G (2005b) Superoxide production by marine microalgae. I. Survey of 37 species from 6 classes. Mar Biol 147:533-540

McDowell EM, Trump BF (1976) Histologic fixatives suitable for diagnostic light and electron microscopy. Arch Pathol Lab Med 100:405-414

Miyashita K, Nara E, Ota T (1993) Oxidative stability of polyunsaturated fatty acids in an aqueous solution. Biosci Biotechnol Biochem 57:1638-1640

> Mooney BD, Nichols PD, de Salas MF, Hallegraeff GM (2007) Lipid, fatty acid and sterol composition of eight species of Kareniaceae (Dinophyta): chemotaxonomy and putative lipid phycotoxins. J Phycol 43:101-111

> Mooney BD, De Salas MF, Hallegraeff GM, Place AR (2009) Survey for karlotoxin production in 15 species of gymnodinioid dinoflagellates (Kareniaceae, Dinophyta). J Phycol 45:164-175

Mooney BD, Hallegraeff GM, Place AR (2010) Ichthyotoxicity of four species of gymnodinioid dinoflagellates (Kareniaceae, Dinophyta) and related karlotoxins. Harmful Algae 9:557-562

Nakayama GR, Maureen CC, Nova MP, Parandoosh Z (1997) Assessment of the Alamar Blue assay for cellular growth and viability in vitro. J Immunol Methods 204:205-208

Oda T, Akaike T, Sato K, Ishimatsu A, Takeshita S, Muramatsu T, Maeda H (1992a) Hydroxyl radical generation by red tide algae. Arch Biochem Biophys 294:38-43

Oda T, Ishimatsu A, Shimada S, Takeshita S, Muramatsu T (1992b) Oxygen-radical-mediated toxic effects of the red tide flagellate Chattonella marina on Vibrio alginolyticus. Mar Biol 112:505-509

Odat T, Moritomi J, Kawano I, Hamaguichi S, Ishimatsu A, Muramatsu T (1995) Catalase- and superoxide dismutaseinduced morphological changes and growth inhibition in red tide phytoplankton Chattonella marina. Biosci Biotech Biochem 59:2044-2048 
Okaichi T (1983) Marine environmental studies on outbreaks of red tides in neritic waters. J Oceanogr Soc Jpn 39: $267-278$

Okuyama H, Orikasa Y, Nishida T (2008) Significance of antioxidative functions of eicosapentaenoic and docosahexaenoic acids in marine microorganisms. Appl Environ Microbiol 74:570-574

Oshima Y, Yamada Sh, Matsunaga K, Moriya T, Ohizumi Y (1994) A monogalactosyl diacylglycerol from a cultured marine dinoflagellate, Scrippsiella trochoidea. J Nat Prod 57:534-536

Pagé B, Pagé M, Noël C (1993) A new fluorometric assay for cytotoxicity measurements in vitro. Int J Oncol 3:473-476

Parrish CC, Bodennec G, Sebedio JL, Gentien P (1993) Intraand extracellular lipids in cultures of the toxic dinoflagellate, Gyrodinium aureolum. Phytochemistry 32:291-295

Pezzolesi L, Cucchiari E, Guerrini F, Pasteris A and others (2010) Toxicity evaluation of Fibrocapsa japonica from the Northern Adriatic Sea through a chemical and toxicological approach. Harmful Algae 9:504-514

Schirmer K, Chan AGJ, Greenberg BM, Dixon DG, Bols NC (1997) Methodology for demonstrating and measuring the photocytotoxicity of fluoranthene to fish cells in culture. Toxicol In Vitro 11:107-119

Shimada M, Akagi N, Nakai Y, Goto H and others (1991) Free radical production by the red tide alga, Chattonella antiqua. Histochem J 23:361-365

Sola F, Masoni A, Fossat B, Porthé-Nibelle J, Gentien P,

Editorial responsibility: Hans Heinrich Janssen,

Oldendorf/Luhe, Germany
Bodennec G (1999) Toxicity of fatty acid 18:5n3 from Gymnodinium cf. mikimotoi: I. morphological and biochemical aspects on Dicentrarchus labrax gills and intestine. J Appl Toxicol 19:279-284

> Urade $\mathrm{R}$, Kito M (1982) Perturbation of lipid metabolism by palmitic acid in Chinese hamster V79-R cells. J Biochem 91:1639-1649

Valentine RC, Valentine DL (2004) Omega-3 fatty acids in cellular membranes: a unified concept. Prog Lipid Res 43: 383-402

- Wardman P (2007) Fluorescent and luminescent probes for measurement of oxidative and nitrosative species in cells and tissues: progress, pitfalls, and prospects. Free Radic Biol Med 43:995-1022

Yamasaki Y, Kim DI, Matsuyama Y, Oda T, Honjo T (2004) Production of superoxide anion and hydrogen peroxide by the red tide dinoflagellate Karenia mikimotoi. J Biosci Bioeng 97:212-215

Yasumoto T, Underdahl B, Aune T, Hormazabal V, Skulberg OM (1990). Screening for hemolytic activity and ichthyotoxic components of Chrysochromulina polylepis and Gyrodinium aureolum from Norwegian coastal waters. In: Graneli E, Sundstrom B, Edler L, Anderson DM (eds) Toxic marine phytoplankton.. Elsevier, New York, NY, p 436-440

Yongmanitchai W, Ward OP (1992) Separation of lipid classes from Phaeodactylum trichornutum using silica cartridges. Phytochemistry 31:3405-3408

Submitted: May 18, 2010; Accepted: January 13, 2011

Proofs received from author(s): March 16, 2011 